\title{
A new genus and species of bristle worm from Beibu Gulf, South China Sea (Annelida, Polychaeta, Amphinomidae)
}

\author{
Yue Sun ${ }^{1,2,3}$, Xinzheng $\mathrm{Li}^{1,2,3}$ \\ I Institute of Oceanology, Chinese Academy of Sciences, Qingdao 266071, China 2 University of Chinese \\ Academy of Sciences, Beijing 100049, China 3 Laboratory for Marine Biology and Biotechnology, Qingdao \\ National Laboratory for Marine Science and Technology, Qingdao, Shandong, 266070, China
}

Corresponding author: Xinzheng Li (lixzh@qdio.ac.cn)

Academic editor: C. Glasby | Received 30 March 2017 | Accepted 21 August 2017 | Published 16 October 2017

http://zoobank.org/ACFDCOF8-9AD8-436F-827B-181DBCD01A73

Citation: Sun Y, Li X (2017) A new genus and species of bristle worm from Beibu Gulf, South China Sea (Annelida, Polychaeta, Amphinomidae). ZooKeys 708: 1-10. https://doi.org/10.3897/zookeys.708.12967

\begin{abstract}
Alleurythoe, a new genus with type species Alleurythoe tenuichaeta sp. n., is described and illustrated based on material from Beibu Gulf, northwestern South China Sea. The new genus is distinguished from all genera within Amphinomidae by a combination of characters: caruncle trilobed, conspicuous, attached to and confluent with the posterior prostomial lobe, which is free from the body wall and has $6-7$ folds on each of the lateral lobes; both noto- and neuropodial aciculae are spinose, extending beyond the chaetal lobe. Alleurythoe tenuichaeta sp. n. is characterized by having branchiae present from chaetiger 4 and a bifurcate neurochaetae capillary. A key distinguishing the genera of Amphinominae is provided.
\end{abstract}

\section{Keywords}

Polychaeta, Amphinomidae, Alleurythoe, new genus, new species, South China Sea

\section{Introduction}

The Amphinomidae, commonly known as fireworms, are typically associated with rocky and soft bottoms in shallow tropical and subtropical waters (Fauchald 1977; Kudenov 1995). It has been reported that amphinomid chaetae are hollow and filled 
with complanine, a trimethylamine compound which is transmitted to predators and causes intense irritation through highly brittle, calcareous harpoon notochaetae (Arias 2013; Day 1967; Kudenov 1993; Penner 1970). By contrast, Tilic et al. (2017) showed that chaetae of Eurythoe complanata (Pallas, 1766) are not hollow; the skin reactions are upon direct contact injury rather than from venom injections. Amphinomid species have either elongate or fusiform bodies, with caruncles generally extending posteriorly over several anterior chaetigers, branchiae ranging from bipinnate to tufts comprised of digitiform rami, with one dorsal and ventral cirrus per parapodium (Fauchald 1977; Gathof 1984; Kudenov 1995).

According to recent phylogenetic studies (Borda et al. 2012, 2015) Amphinomidae can be subdivided into two subfamilies based on the presence (Archinominae Kudenov, 1991) or absence (Amphinominae Lamarck, 1818) of accessory dorsal cirrus. The subfamily Amphinominae currently includes Amphinome Bruguière, 1789, Cryptonome Borda, Kudenov, Bienhold \& Rouse, 2012, Eurythoe Kinberg, 1857, Hermodice, Kinberg, 1857, Hipponoe Audouin \& Milne Edwards, 1830, Paramphinome Sars, 1869, and Pareurythoe Gustafson, 1930; Benthoscolex Horst, 1912, Branchamphinome Hartman, 1967, Linopherus Quatrefages, 1866, and Pherecardia Horst, 1886 are provisionally included.

The purpose of this paper is to describe a new genus and species of Amphinominae based on specimens deposited in the Marine Biological Museum of the Chinese Academy of Sciences. A key distinguishing the genera of the Amphinominae, modified from Borda (2012), is provided.

\section{Materials and methods}

Specimens examined in present paper are deposited in the Marine Biological Museum of the Chinese Academy of Sciences (MBMCAS) in the Institute of Oceanology (IOCAS), preserved in 75\% ethanol solution. A Zeiss Stemi 2000-C stereomicroscope with an AxioCam MRc 5 digital camera was used for observations and drawing.

\section{Systematics}

Family Amphinomidae Lamarck, 1818

Subfamily Amphinominae Lamarck, 1818

Genus Alleurythoe gen. n.

http://zoobank.org/E7B84024-A184-4D44-91AD-DE018B9B70D2

Type species. Alleurythoe tenuichaeta sp. $\mathrm{n}$.

Diagnosis. Body elongate, quadrangular. Caruncle trilobed, attached to and confluent with posterior prostomial lobe, free from body wall, median lobe broadly sinusoidal, 
each lateral lobe with 6-7 folds, supported by a basal plate. Branchiae present from chaetiger 4 , dendritically branched. Bifurcate neurochaetae capillary. Both noto- and neuropodial aciculae spinose.

Etymology. The generic name is a combination of the prefix allo- (meaning "other" or "alternative" in Greek) and the generic name Eurythoe. The new genus is assigned to the subfamily Amphinominae and most similar to Eurythoe in morphology. Gender: feminine.

Remarks. Alleurythoe gen. $n$. is assigned to the subfamily Amphinominae Lamarck, 1818 because of the absence of accessory dorsal cirri, and justified as a new genus by the nature of its caruncle (Yánez-Rivera 2011). The new genus is anatomically similar to Notopygos Grube, 1855 and Chloeia Lamarck, 1818 in the shape of caruncle which is trilobed and essentially supported by a basal plate. However, in contrast to Alleurythoe gen. $n$., the caruncle in the latter two genera has an elevated median keel with several bilateral folds, and it is usually fused to the body wall on chaetigers 1-2 and free thereafter. In the new genus, median keel of caruncle is broadly sinusoidal, thickened, lacks bilateral folds, and is attached to, and confluent with the posterior prostomial lobe, and free from the body wall. In addition, Alleurythoe differs from most other amphinomids in having spinous rather than hastate aciculae, bifurcate neurochaetae capillary, while other amphinomids with heftier bifurcate neurochaetae.

Alleurythoe gen. n. is superficially similar to Eurythoe Kinberg, 1857 in the shape of caruncle, which in both genera consists of a flattened, pronounced median keel and folded lateral lobes; however, the caruncle of Eurythoe Kinberg, 1857 is fused to the body wall for most of its length, the median keel overlaps the lateral lobes, which are scalloped on each side and lack a basal plate (Bindra 1927; Borda 2012; Day 1967). Further, in the new genus, the neurochaetae are capillary (non-spurred or spurred), while the short, thick bifurcate neurochaetae, typical of Eurythoe Kinberg, 1857, are absent. An identification key to the genera of Amphinominae modified from Borda (2012) is provided below.

\section{Alleurythoe tenuichaeta sp. $\mathbf{n}$.}

http://zoobank.org/6BD0D01F-5705-433A-8ABE-250DA5B6D64B

Figs $1-2$

Material examined. Holotype, MBM200146, Beibu Gulf, $20^{\circ} 15^{\prime} \mathrm{N}, 109^{\circ} 15^{\prime} \mathrm{E}, 38$ meters, mud, coll. Ruiping Sun, 27 August 1962. Paratype: MBM010006, Beibu Gulf, $19^{\circ} 30^{\prime} \mathrm{N}, 108^{\circ} 30^{\prime} \mathrm{E}, 66$ meters, mud, coll. Zhengang Fan, 14 May 1960.

Measurements. Holotype incomplete, with anterior fragment and posterior fragment, without posterior end. Anterior fragment with 62 chaetigers, $71 \mathrm{~mm}$ long, and $10 \mathrm{~mm}$ maximum width, posterior fragment with 50 chaetigers, $60 \mathrm{~mm}$ long. Paratype complete, broken into two fragments. Anterior fragment with 60 chaetigers, $75 \mathrm{~mm}$ long, and $8 \mathrm{~mm}$ maximum width, posterior fragment with 61 chaetigers, $57 \mathrm{~mm}$ long.

Diagnosis. Body elongate, quadrangular. Caruncle trilobed, conspicuous, attached to and confluent with posterior prostomial lobe, free from body wall, median lobe 


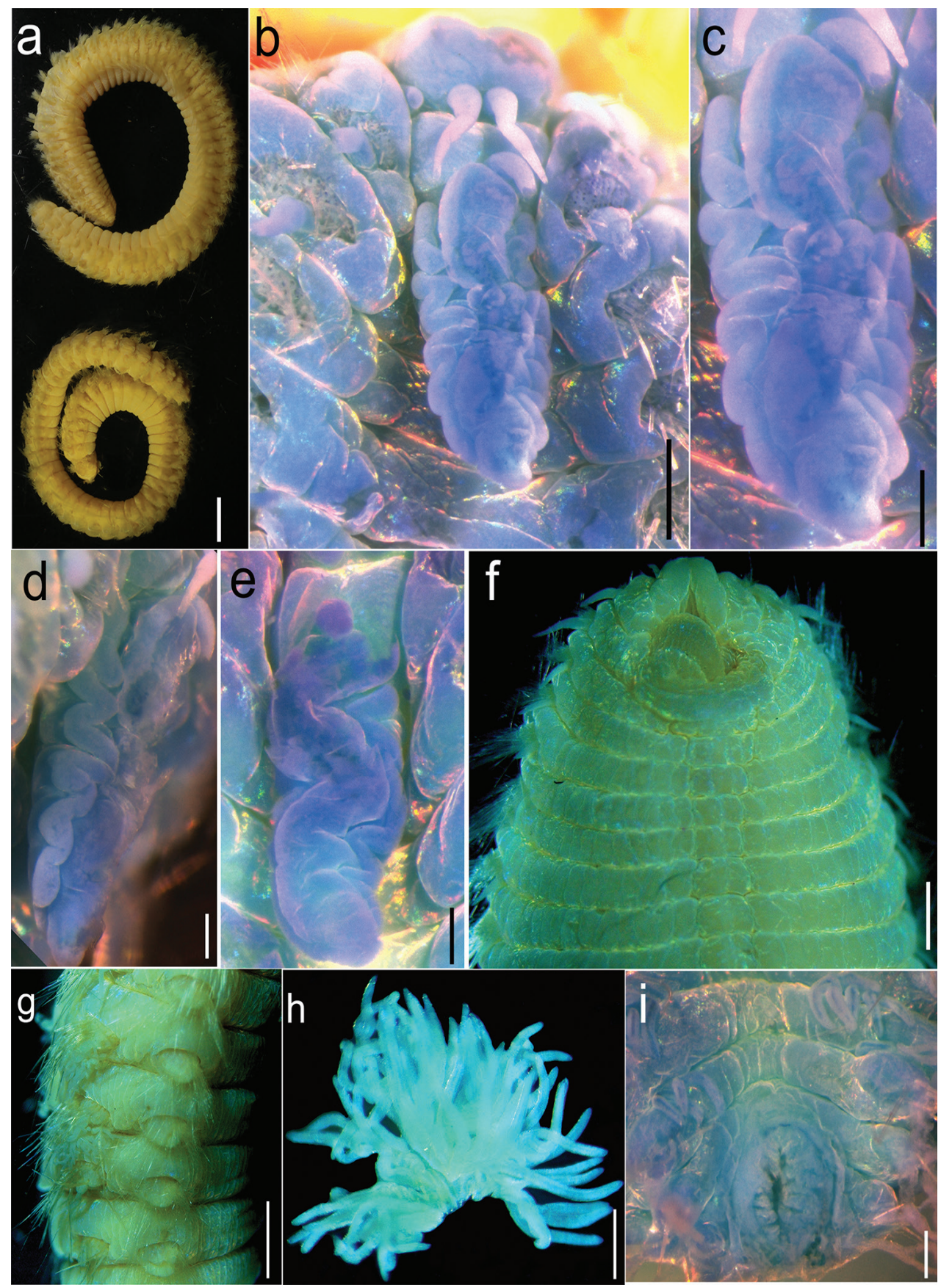

Figure I. Alleurythoe tenuichaeta gen. n. \& sp. n., a Entire animal in lateral view b Prostomium and caruncle, dorsal view c Caruncle, dorsal view $\mathbf{d}$ Caruncle, lateral view. Caruncle, dorsal view $\mathbf{f}$ Anterior chaetigers, ventral view $\mathbf{g}$ Parapodia of middle chaetigers, lateral view $\mathbf{h}$ Branchia of posterior chaetiger i pygidium, dorsal view. a-d, f-i holotype e paratype. Scale bars a $0.5 \mathrm{~cm} ; \mathbf{b} 0.5 \mathrm{~mm}, \mathbf{c} 0.25 \mathrm{~mm}$; d-e, i $0.2 \mathrm{~mm} ; \mathbf{f} 1 \mathrm{~mm} ; \mathbf{g} 2 \mathrm{~mm}$; h $0.5 \mathrm{~mm}$. 
broadly sinusoidal, each lateral lobe with 6-7 folds, supported by a basal plate. Parapodia biramous, with thickened collars encompassing noto- and neuropodial fascicular lobes; chaetiger 2 first complete anteriormost annular ring. Branchiae present from chaetiger 4, continuing almost to end of body, dendritically branched. Notochaetae coarser and shorter than neurochaetae, include harpoon chaetae and capillaries; barbs of harpoon chaetae on anteriormost chaetigers absent to few in number, better developed in following chaetigers. Bifurcate neurochaetae capillary.

Description. Type specimens preserved alcohol pale, without pigmentation. Body quadrangular in cross section, middle region enlarged, tapering posteriorly (Fig. 1a).

Prostomium rectangular, divided into two parts by transverse groove. Anterior lobe prominent, slightly bilobed anteriorly, with two palps and two lateral antennae, palps on ventrolateral part (Fig. 2a, b), lateral antennae subulate, emerging on posterior edge of anterior lobe, similar in shape and size to palps. Posterior lobe rectangular, slightly smaller than anterior one, with median antenna, digitiform, emerging in front of caruncle, short, extending back only to first chaetiger (Figs 1b; 2a). Two pairs of eyes present. Buccal opening occupying two chaetigers (Figs 1f; 2b). Caruncle trilobed, conspicuous, about 2 times as long as prostomium, attached to and confluent with posterior prostomial lobe, free from body wall, extremity tapering, extending back to middle of fourth chaetiger, median keel broadly sinusoidal, lateral lobes plicate each with approximately 6-7 folds (Figs $1 \mathrm{~b}-\mathrm{e} ; 2 \mathrm{a}$ ), located slightly behind posterior prostomial lobe, supported by a basal plate. Pharynx unarmed, sac-like (Figs 1f; 2b).

All parapodia biramous, with thickened collars encompassing noto- and neuropodial fascicular lobes. Chaetiger 1 greatly reduced, incomplete dorsally and ventrally. Chaetiger 2 surrounding mouth posteriorly, represents first complete segmental ring (Figs 1f; 2b), with distinctly separated notopodia and neuropodia (Figs 1g, 2c); dorsal and ventral cirri conical and digitiform, respectively, both with stout basal cirrophores and slender distal cirrostyles; cirri of anterior 2 chaetigers longer than those of following chaetigers.

Branchiae present from chaetiger 4, dendritically branched, filaments densely ciliated (Figs 1h, 2a). First branchia with eight terminal filaments, best developed branchiae with $43-46$ terminal filaments in $21-53$ chaetigers, reducing posteriorly to four or five filaments, the last three chaetigers without branchiae.

Notochaetae coarser and shorter than neurochaetae. Notochaetae of three kinds: simple chaetae (harpoon chaetae without barbs, Fig. 2d), stout harpoon chaetae, greatly reduced in anterior chaetigers (Fig. 2e-g), well developed on following chaetigers (Fig. 2h); and slender capillary chaetae. Notoaciculae spinose, numbering 4-6 per fascicle, (Fig. 2i), arranged in row immediately in front of dorsal cirri, extending beyond chaetal lobe. Chaetiger 5 with 20 simple chaetae and few capillary chaetae; chaetiger 14 with six harpoon chaetae (with 8-9 barbs), 12 harpoon chaetae (without barbs) and 12 capillary chaetae; middle and posterior chaetigers each with 19-22 harpoon chaetae (each with about 23 coarse barbs) and 21-23 capillary chaetae. Neurochaetae of one basic kind: capillaries with or without spurs (Fig. 2j), the former with smooth long prongs 3-4 times length of short prongs (Fig. 2k-m). Neuroaciculae spinose, numbering 7-9, extending beyond neuropodial lobe, arranged along dorsal superior region of fascicle (Fig. 2n). 


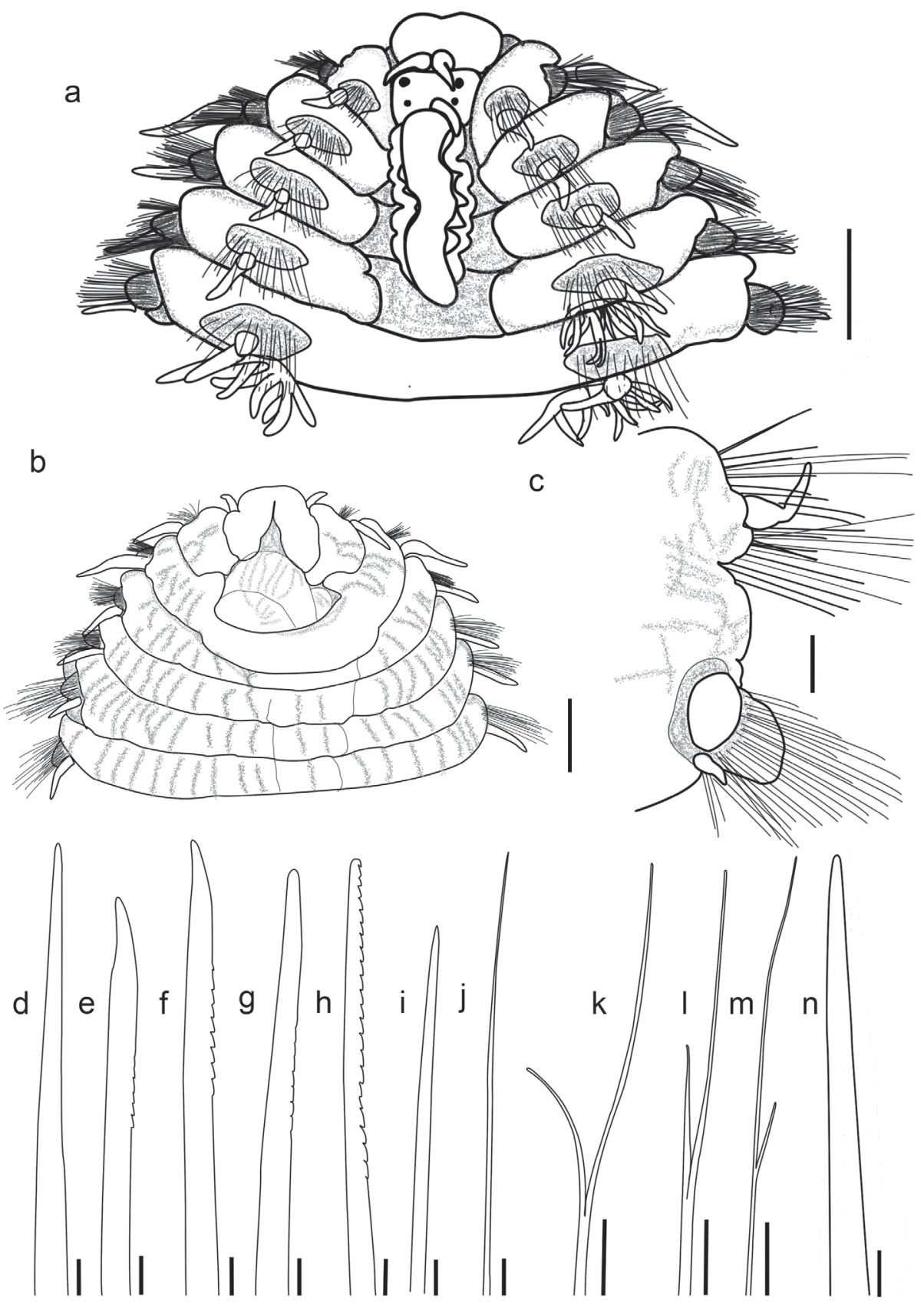

Figure 2. Alleurythoe tenuichaeta gen. n. \& sp. n., holotype. a Anterior chaetigers, dorsal view b Anterior chaetigers, ventral view $\mathbf{c}$ Parapodia of middle chaetiger, posterior view $\mathbf{d}$ Greatly reduced harpoon chaeta, notopodium of chaetiger $5 \mathbf{e}-\mathbf{g}$ Reduced harpoon chaeta, notopodium of chaetiger $14 \mathbf{h}$ Harpoon chaeta, notopodium of chaetiger $106 \mathbf{i}$ Acicula, notopodium of chaetiger $106 \mathbf{j}$ Capillary chaeta, neuropodium of chaetiger $85 \mathbf{k}$ Bifurcate chaeta, neuropodium of chaetiger $22 \mathbf{~} \mathbf{- m}$ Bifurcate chaetae, neuropodium of chaetiger $85 \mathbf{n}$ Simple chaeta, neuropodium of chaetiger 85 . Scale bars: a-b $1 \mathrm{~mm} ; \mathbf{c} 0.5 \mathrm{~mm}$; d-n $50 \mu \mathrm{m}$. 
Paratype: Pygidium with dorsal anus opening on last three chaetigers (Fig. 1i), pygidial cirrus with rounded anal papilla.

Etymology. The name of this species refers to the slender form of its capillary neurochaetae.

Distribution. Presently known only from the type location, Beibu Gulf, South China Sea.

Remarks. Alleurythoe tenuichaeta sp. n. is anatomically similar to Eurythoe rullieri Fauvel, 1953 because the caruncle of both species is free from the body wall. For example, the relatively narrow median keel of Alleurythoe tenuichaeta sp. n., does not overlap the lateral lobes, while that of Eurythoe rullieri broadly overlaps the contiguous lateral lobes. The new species is further differentiated in having branchiae first present from chaetiger 4, rather than chaetiger 3, and lacking the thick bifurcate neurochaetae that are characteristic of E. rullieri and the genus Eurythoe (Fauvel 1953).

Alleurythoe tenuichaeta sp. n. also resembles E. paupera (Grube 1856) in having quadrangular body form, branchiae first present from the fourth chaetiger. However, caruncles and notochaetae differ in these species. The caruncle of Alleurythoe tenuichaeta is attached to and confluent with the posterior prostomial lobe, and free of the body wall, while the caruncle of E. paupera is fixed to the first two chaetigers, extending to the anterior edge of the third chaetiger. Meanwhile, A. tenuichaeta sp. n. has harpoon notochaetae and bifurcate neurochaetae, both of which are absent in E. paupera (Grube 1856).

\section{Key to genera of Amphinominae Lamarck, 1818 (modified from Borda 2012)}

1 Caruncle absent, neuropodia arising from ventral body surface; neurochaetae retractile. Hipponoe Audouin \& Milne Edwards, 1830

- $\quad$ Caruncle present, variably developed, neuropodia arising from lateral body surface; neurochaetae non-retractile

2 Branchiae present on all chaetigers Branchamphinome Hartman, 1967 Some chaetigers without branchiae Branchiae present from chaetiger 6, eyes absent ...Benthoscolex Horst, 1912 Branchiae present from chaetiger 2-4, eyes commonly present Chaetiger 1 dorsally continuous, complete....

Chaetiger 1 dorsally discontinuous, incomplete Stout, distally curved hooks present in notopodia of chaetiger 1; caruncle round, sessile, without free lateral wings; neurochaetae not unidentate; harpoon notochaetae with 1 row of barbs

Paramphinome Sars, 1869 Stout, distally curved hooks not present in notopodia of chaetiger 1; caruncle stalked, broadly triangular to chordate with free lateral wings; neurochaetae unidentate; harpoon notochaetae with up to 5 rows of barbs

Amphinome Bruguière, 1789

Caruncle small and inconspicuous, not extending beyond one external chaetiger posteriorly 
- $\quad$ Caruncle large and conspicuous, extending beyond one external chaetiger posteriorly

7 Branchiae present on almost all chaetigers, with modified neurochaetae ........

Cryptonome Borda, Kudenov, Bienhold \& Rouse, 2012

- Branchiae restricted to anterior chaetigers, neurochaetae unmodified

Linopherus Quatrefages, 1866

Caruncle with smooth median keel, with oblique divergent lateral lobes

Pherecardia Horst, 1886

- $\quad$ Caruncle with or without median keel, lateral lobes not oblique divergent......9

9 Caruncle without a median lobe, with paired lateral lobes forming a complex monopodial-like pattern of bipinnate chevrons opening anteriorly

Hermodice Kinberg, 1857

- $\quad$ Caruncle with a smooth median lobe, with paired lateral lobes not forming a complex monopodial-like pattern of bipinnate chevrons opening anteriorly ... 10

10 Caruncle sinusoidal, median keel not thickened, not pronounced, fused to body wall for most of its length.................... Pareurythoe Gustafson, 1930

- $\quad$ Median keel of caruncle sinusoidal, attached to and confluent with posterior prostomial lobe, supported by a basal plate and free of body wall, median keel not overlapping lateral lobes; branchiae present from chaetiger four, bifurcate neurochaetae capillary, slender

Alleurythoe gen. n. Caruncle not sinusoidal, fused to body wall for most of its length, without basal plate, median keel thickened and pronounced, overlapping lateral lobes; branchiae present from chaetigers 1-4, bifurcate neurochaetae short and thick

Eurythoe Kinberg, 1857

\section{Acknowledgements}

We are grateful to Dr. Jerry D. Kudenov (Biological Sciences, University of Alaska Anchorage, Anchorage, Alaska), Dr. Elizabeth Borda (Marine Biology Department, Texas A\&M University) and Dr. Melih Ertan Çinar (Ege University, Faculty of Fisheries, Department of Hydrobiology, Izmir, Turkey) for giving us valuable comments on the manuscript and providing important references. We thank Dr Chris Glasby for his assistance in language. We also thank the managers of the Marine Biological Museum of the Chinese Academy of Sciences for their help in sorting the studied material. This study was supported by the National Natural Science Foundation of China (No. 41406157).

\section{References}

Arias A, Barroso R, Anadón N, Paiva PC (2013) On the occurrence of the fireworm Eurythoe complanata complex (Annelida, Amphinomidae) in the Mediterranean Sea with an 
updated revision of the alien Mediterranean amphinomids. ZooKeys 337: 19-33. https:// doi.org/10.3897/zookeys.337.5811

Baird W (1868) Contributions towards a monograph of the species of annelids belonging to the Amphinomacea, with a list of the known species, and a description of several new species (belonging to the group) contained in the National Collection of the British Museum. To which is appended a short account of two hitherto nondescript annulose animals of a larval character. The Journal of the Linnean Society of London, Zoology 10: 215-250. https:// doi.org/10.1111/j.1096-3642.1868.tb02233.x

Bindra SS (1927) Fauna of Karachi 1. A study of the genus Eurythoe (family Amphinomidae). Memoirs of the Department of Zoology, Punjab University 1: 1-18.

Borda E, Kudenov JD, Bienhold C, Rouse GW (2012) Towards a revised Amphinomidae (Annelida, Amphinomida): description and affinities of a new genus and species from the Nile Deep-sea Fan, Mediterranean Sea. Zoologica Scripta 41(3): 307-325. https://doi. org/10.1111/j.1463-6409.2012.00529.x

Borda E, Yáñez-Rivera B, Ochoa GM, Kudenov JD, Sanchez-Ortiz C, Schulze A, Rouse GW (2015) Revamping Amphinomidae (Annelida: Amphinomida), with the inclusion of Notopygos. Zoologica Scripta 44(3): 324-333. https://doi.org/10.1111/zsc.12099

Cinar ME (2008) Description of a new fireworm, Eurythoe turcica sp. nov. (Polychaeta: Amphinomidae), from the Levantine coast of Turkey (eastern Mediterranean), with re-descriptions of Eurythoe parvecarunculata Horst and Amphinome djiboutiensis Gravier based on type material. Journal of Natural History 42(29): 1975-1990. https://doi. org/10.1080/00222930802140194

Day JH (1967) A monograph on the Polychaeta of Southern Africa. Part 1. Errantia. British Museum (Natural History), London, 1-458.

Tilic E, Pauli B, Bartolomaeus T (2017) Getting to the root of fireworms' stinging chaetaechaetal arrangement and ultrastructure of Eurythoe complanata (Pallas, 1766) (Amphinomida). Journal of morphology 278(6): 865-876. https://doi.org/10.1002/jmor.20680

Fauchald K (1977) The polychaete worms, definitions and keys to the orders, families and genera. Natural History Museum of Los Angeles County, Los Angeles, Science Series 28: $100-103$.

Fauvel P (1953) Annélides Polychètes Non Pélagiques. Expédition Océanographique Belge dans les eaux côtières africaines de l'Atlantique Sud Institut Royale des Sciences Naturelles de Belgique 4(4): 13-17.

Gathof JM (1984) Family Amphinomidae Savigny, 1818. In: Uebelacker JM, Johnson PG (Eds) Taxonomic guide to the polychaetes of the northern Gulf of Mexico. Final report to the Mineral Management Service, contract 14-152-29091. Barry A. Vitor \& Ass., Inc., Mobile, Alabama, Vol. V, 37-1/37-12.

Grube AE (1856) Annulata Örstediana. Enumeratio Annulatorum, quae in itinere per Indiam occidentalem et Americam centralem annis 1845-1848 suscepto legit cl. A.S. Örsted, adjectis speciebus nonnullis a cl. H. Kröyero in itinere ad Americam meridionalem collectis. Videnskabelige Meddelelser fra Dansk naturhistorisk Forening i Köbenhavn 1856: 44-62.

Kinberg JGH (1857) Nya slägten och arter af Annelider. Öfversigt af Kongliga VetenskapsAkademiens Förhandlingar, Stockholm 14(1): 11-14. 
Kudenov JD (1993) Amphinomidae and Euphrosinidae (Annelida: Polychaeta) principally from Antarctica, the Southern Ocean, and Subantarctic regions. Antarctic Research Series 58: $93-150$.

Kudenov JD (1995) Family Amphinomidae Lamarck, 1818[J]. Taxonomic atlas of the benthic fauna of the Santa Maria Basin and Western Santa Barbara Channel 5: 207-215. https:// doi.org/10.1029/AR058p0093

Lamarck JB (1818) Histoire Naturelle des Animaux Sans Vertebres. Deterville Libraire, Verdicre Libraire, Paris, 5: 411-612.

Penner LR (1970) Bristleworm stinging in a natural environment. University of Connecticut Occasional Papers (Biological Sciences Series) 1: 275-280.

Tilic E, Pauli B, Bartolomaeus T (2017) Getting to the root of fireworms' stinging chaetaechaetal arrangement and ultrastructure of Eurythoe complanata (Pallas, 1766) (Amphinomida). Journal of morphology 278(6): 865-876. https://doi.org/10.1002/jmor.20680

Yáñez-Rivera B, Salazar-Vallejo SI (2011) Revision of Hermodice Kinberg, 1857 (Polychaeta: Amphinomidae) [J], Scientia Marina 75(2): 251-262. https://doi.org/10.3989/scimar.2011.75n2251 